DOI: $10.21802 / \operatorname{artm} .2019 .3 .11 .33$.

УДК 616-005.6+616.147.17-007.64+616-071+616-089

\title{
ГОСТРИЙ ТРОМБОЗ ГЕМОРОЇДАЛЬНИХ ВУЗЛІВ: КЛІНІЧНИЙ ПРОФІЛЬ ПАЦІЕНТА ТА ЛІКУВАЛЬНА ТАКТИКА
}

\author{
Ю.Б. Кіндракевич, В.І. Пилипчук, А.Л. Шаповал
}

Івано-Франківський наџіональний медичний університет, кафедра хірургї № 2 та кардіохірургї̈,

м. Івано-Франківськ, Украӥна,

ORCID ID: 0000-0003-2891-8035,

ORCID ID: 0000-0002-3754-4592,

ORCID ID: 0000-0002-7950-1451,

e-mail:kjb82@ukr.net

Резюме. Мета дослідження - визначити клінічний профіль пацієнта та порівняти результати консервативного та хірургічного лікування гострого тромбозу гемороїдальних вузлів.

Методи. Протягом 2014-2018 pр. у проктологічному відділенні Івано-Франківської обласної клінічної лікарні лікувались 98 пацієнтів з гострим тромбозом гемороїдальних вузлів. Серед них 60 (61,2 \%) чоловіків, 38 $(38,8$ \%) жінок. Для визначення клінічного профілю пацієнтів 3 гострим тромбозом гемороїдальних вузлів вивчали скарги при поступленні, можливі причини виникнення захворювання, тривалість захворювання до звернення за допомогою, дані об'єктивного обстеження. Зв'язок між скаргами та даними об'єктивного обстеження визначали за допомогою коефіцієнтів асоціації та контингенції. Оцінювали вплив консервативного та хірургічного лікування гострого тромбозу гемороїдальних вузлів на тривалість застосування ненаркотичних анальгетиків та терміни перебування у стаціонарі.

Результати дослідження. У пацієнтів з гострим тромбозом гемороїдальних вузлів І ступеня тяжкості тривалість прийому ненаркотичних анальгетиків та терміни перебування у стаціонарі скорочуються у 1,8 та 1,7 рази відповідно, при проведенні тромбектомії у 1,7 та 1,6 рази відповідно при проведенні тромбектомії в поєднанні 3 некректомією. Тривалість прийому ненаркотичних анальгетиків скорочується у 1,4 рази при

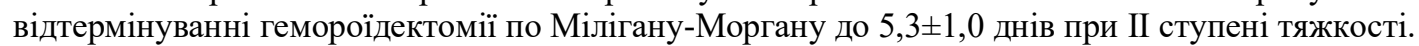

Висновки. При гострому тромбозі гемороїдальних вузлів І ступеня тяжкості потрібно дотримуватись активної хірургічної тактики, при II-III ступені тяжкості проводити хірургічне лікування після зменшення набряку, ознак запалення та курсу консервативної терапії.

Ключові слова: геморой, тромбоз, гострий, клініка, лікування.

Вступ. Частка геморою серед хвороб прямої кишки складає близько $42 \%$ [3]. Перебіг хронічного геморою ускладнюється гострим тромбозом гемороїдальних вузлів (ГТГВ) або кровотечею. ГТГВ повторюється 3 частотою від 2-ох до 7-ми разів на рік у 51-67 \% пацієнтів [2]. Під час кожного загострення період тимчасової непрацездатності становить від 6 до 35 днів [4].

Обгрунтування дослідження. Геморой $\epsilon$ найчастішою проблемою порушення здоров'я в країнах Європи та США, випереджаючи гастроезофагеальну рефлюксну хворобу та хвороби, що передаються статевим шляхом. Складно визначити фактичну частоту гемороїдальних захворювань, оскільки багато пацієнтів не звертаються за медичною допомогою, про що свідчить поширеність геморою від 4 $\%$ до 40 \% у різних дослідженнях [9]. Однак, недавні дані свідчать про збільшення поширеності геморою. У епідеміологічному дослідженні геморою в США виявлено поширеність 4,4 \%, у Південній Кореї та Австрії поширеність геморою у дорослого населення становила 14,4 \% [6] і 38,9 \% [9] відповідно.

При ГТГВ використовують консервативні та хірургічні методи лікування. До теперішнього часу немає єдиної думки 3 приводу тактики лікування ГТГВ. Одні автори вважають доцільним проводити консервативне лікування $[8,5]$, а інші оперують хворих у гострій стадії запалення або проводять протизапальне лікування і оперують після стихання запальних явищ [1].

Мета дослідження. Вивчити клінічний профіль пацієнтів, які звертаються за допомогою 3 приводу ГТГВ, та встановити зв'язок між скаргами та даними об'єктивного обстеження за допомогою визначення коефіцієнтів асоціації та контингенції. Проаналізувати вплив методів лікування ГТГВ на тривалість застосування ненаркотичних анальгетиків та перебування у стаціонарі.

Матеріали і методи. Впродовж 2014-2018 років у проктологічному відділенні ІваноФранківської обласної клінічної лікарні лікувались 3 приводу геморою 504 хворих. Серед них 98 пацієнтів 3 ГТГВ, що становить 19,4\% від всіх пацієнтів з гемороєм. Чоловіків було 60 (61,2 \%), жінок - 38 (38,8 \%). Середній вік пацієнтів становив $47,9 \pm 15,3$ років (діапазон 25-86 років). Середній вік чоловіків значно не відрізнявся від віку жінок $(47,1 \pm 15,9$ проти $50,4 \pm 14,5, \mathrm{p}>0,05)$. 
Для визначення клінічного профілю вивчали скарги пацієнтів при поступленні, можливі причини виникнення захворювання, тривалість захворювання до звернення за допомогою, дані об'єктивного обстеження пацієнтів. Симптоми описані пацієнтами у порядку зменшення: біль виявлено у 98 (100,0 \%) хворих, наявність «утворення» в анальній ділянці у 69 (70,4 \%) хворих, кровотеча у 50 (51,0 \%) хворих, випадіння вузлів під час акту дефекації у 42 (42,9\%) хворих, затримка стільця у 18 (18,4 \%) хворих. Час від початку появи симптомів до звернення за лікарською допомогою становив від 1-ї до 14-ти діб (медіана - 3 доби). Можливими причинами виникнення ГТГВ пацієнти вважають: фізичне навантаження -12 (12,2 \%) хворих, закреп - 39 (39,8 \%) хворих, діарею - 8 $(8,2 \%)$ хворих, вживання гострої їжі - 13 (13,3\%) хворих та алкоголю - 12 (12,2 \%) хворих, випадіння гемороїдальних вузлів та їхнє механічне пошкодження - 27 (27,6 \%) хворих. У 57 (58,2 \%) пацієнтів у минулому були епізоди ГТГВ або симптоми, характерні для хронічного геморою. При об'єктивному обстеженні тромбовані гемороїдальні вузли виявлено у 98 (100,0 \%) пацієнтів, ерозію та некроз тканин над тромбованими гемороїдальними вузлами у $52(53,1 \%)$ хворих, набряк тканин в перианальній ділянці у 34 (34,7\%) хворих. Скарги пацієнта та дані об'єктивного обстеження являються атрибутивними (якісними) ознаками. Оцінку зв'язку між атрибутивними ознаками проводили за допомогою визначення коефіцієнтів асоціації і контингенції [7]. Для їхнього обчислення будується чотириклітинна таблиця (табл. 1), яка показує зв'язок між двома ознаками, кожна 3 яких повинна бути альтернативною, тобто такою, що складається 3 двох якісно відмінних один від одного значень (наприклад, скарги на кровотечу або відсутність такої, наявність або відсутність некрозу тканин над тромбованим гемороїдальним вузлом).

Таблиця 1

Чотириклітинна таблиця для розрахунку коефіціснтів асоціації і контингенції

\begin{tabular}{|c|c|c|c|}
\hline Ознаки & $\mathrm{A}$ & $\mathrm{He} \mathrm{A}$ & $\Sigma \mathrm{B}$ \\
\hline $\mathrm{B}$ & $\mathrm{a}$ & $\mathrm{b}$ & $\mathrm{a}-\mathrm{b}$ \\
$\mathrm{He} \mathrm{B}$ & $\mathrm{c}$ & $\mathrm{d}$ & $\mathrm{c}-\mathrm{d}$ \\
$\Sigma \mathrm{A}$ & $\mathrm{a}-\mathrm{c}$ & $\mathrm{b}-\mathrm{d}$ & $\mathrm{N}$ \\
\hline
\end{tabular}

У цій таблиці А і В ознаки, між якими вивчається зв'язок; не А і не В - протилежні (альтернативні) ознаки: a, b, c, d - частоти відповідних комбінацій ознак; $\mathrm{N}$ - загальне число спостережень.

Формули для визначення коефіцієнтів

$$
\text { контингенції } \mathrm{r}_{\mathrm{k}}=\frac{\mathrm{ad}-\mathrm{bc}}{\sqrt{(\mathrm{a}+\mathrm{b})(\mathrm{c}+\mathrm{d})(\mathrm{a}+\mathrm{c})(\mathrm{b}+\mathrm{d})}}
$$

асоціації $\left(\mathrm{r}_{\mathrm{a}}\right)$ та контингенції $\left(\mathrm{r}_{\mathrm{k}}\right)$ :

$$
\text { acoціації } r_{a}=\frac{a d-b c}{a d+b c}
$$

Коефіціснти асоціації і контингенції можуть приймати будь-які значення від -1 до +1 . Коефіцієнт контингенції завжди менший від коефіцієнта асоціації. Зв'язок вважається підтвердженим, якщо $r_{a}>$ 0,5 або $\mathrm{r}_{\mathrm{k}}>0,3$.

Проведено порівняння консервативного та хірургічних методів лікування в залежності від ступеня тяжкості ГТГВ. Для цього пацієнтів розділено на дві групи. Першу групу склали 27 (27,6\%) пацієнтів з ГТГВ, яким проводили консервативне лікування. 3 них 13 (48,2 \%) хворих з ГТГВ І ступеня тяжкості, 10 (37,0 \%) хворих з ГТГВ II ступеня тяжкості, 4 (14,8 \%) хворих з ГТГВ ІІІ ступеня тяжкості. Консервативне лікування включало використання венотоніків, комбінованих свічок та мазей із знеболювальною i протизапальною дією. Другу групу склав 71 (72,5 \%) пацієнт, якому проводили оперативне лікування. 3 них $51(71,8 \%)$ хворий з ГТГВ I ступеня тяжкості, 16 (22,5\%) хворих з ГТГВ II ступеня тяжкості, 4 (5,6 \%) хворих з ГТГВ III ступеня тяжкості. Оцінювали вплив вибраного методу лікування ГТГВ в залежності від ступеня тяжкості ГТГВ на тривалість застосування ненаркотичних анальгетиків та строки перебування у стаціонарі.

Результати дослідження та їх обговорення. Серед звернень за медичною допомогою 3 приводу геморою п'яту частину становлять пацієнти з ГТГВ. В основному це пацієнти працездатного віку. Для гострого тромбозу гемороїдальних вузлів характерна тріада симптомів: біль, кровотеча, наявність «утворення» в анальній ділянці. Звернення за допомогою протягом трьох днів від початку захворювання свідчить про виражений больовий синдром. При визначенні коефіцієнтів асоціації та контингенції встановлено зв'язок між такими скаргами та даними об'єктивного обстеження: наявність «утворення» в анальній ділянці та набряк тканин анальної ділянки, кровотеча та некроз тканин над тромбованим гемороїдальним вузлом, затримка стільця та набряк тканин анальної ділянки (табл. 2).

У 35 (70,0 \%) пацієнтів зі скаргами на кровотечу при об'єктивному обстеженні виявлено некроз тканин над тромбованим вузлом. У 18 (26,0\%) пацієнтів, які скаржились на наявність «утворення» в анальній ділянці, спостерігався набряк тканин цієї ділянки. Також набряк тканин спостерігався у 11 (61,1 \%) пацієнтів із затримкою стільця.

Кількість пацієнтів з ГТГВ І ступеня тяжкості становила 64 (65,3 \%) особи. Консервативне лікування отримували $13 \quad(20,3$ \%) пацієнтів. Хірургічне лікування отримував 51 (79,7\%) пацієнт, 3 них у 12 (23,5\%) хворих проведено тромбектомію, у $19(37,3 \%)$ хворих - тромбектомію та некректомію, у 20 (39,2 \%) хворих - операцію Мілігана-Моргана. Консервативне лікування отримували пацієнти, у яких вперше виник тромбоз, які не мали ознак хронічного геморою та які мали ознаки хронічного геморою, але відмовились від проведення оперативного втручання. Тромбектомію проводили пацієнтам, у яких тромбоз виникав повторно та не було ознак хронічного геморою, а також пацієнтам 3 ознаками хронічного геморою, які відмовились від радикальної гемороїдектомії по Мілігану-Моргану. 
Зв'язок між скаргами та даними об'єктивного обстеження паціснтів з гострим тромбозом гемороїдальних вузлів

\begin{tabular}{|c|l|c|c|c|c|}
\hline \multicolumn{2}{|c|}{} & \multicolumn{1}{|c|}{$\begin{array}{c}\text { Наявність } \\
\text { «утворення» }\end{array}$} & Кровотеча & $\begin{array}{c}\text { Випадіння } \\
\text { гемороїдальних } \\
\text { вузлів }\end{array}$ & $\begin{array}{c}\text { Затримка } \\
\text { стільця }\end{array}$ \\
\hline \multirow{2}{*}{$\begin{array}{l}\text { Некроз } \\
\text { тканин }\end{array}$} & $\begin{array}{l}\mathrm{N}, \text { кількість } \\
\text { хворих }\end{array}$ & 53 & 35 & 21 & 7 \\
\cline { 2 - 6 } & $\mathrm{r}_{\mathrm{a}}$ & 0,28 & 0,63 & $-0,12$ & $-0,35$ \\
\cline { 2 - 6 } & $\mathrm{r}_{\mathrm{k}}$ & 0,14 & 0,36 & $-0,06$ & $-0,14$ \\
\hline \multirow{2}{*}{$\begin{array}{l}\text { Набряк } \\
\text { тканин }\end{array}$} & $\begin{array}{l}\mathrm{N}, \text { кількість } \\
\text { хворих }\end{array}$ & 18 & 7 & 7 & 11 \\
\cline { 2 - 6 } & $\mathrm{r}_{\mathrm{a}}$ & 1,0 & $-0,26$ & $-0,09$ & 0,88 \\
\cline { 2 - 6 } & $\mathrm{r}_{\mathrm{k}}$ & 0,33 & $-0,1$ & $-0,03$ & 0,52 \\
\hline
\end{tabular}

Некректомію та тромбектомію проводили пацієнтам з некрозом тканин над гемороїдальними вузлами без ознак хронічного геморою, а також у пацієнтів з некрозом тканин над тромбованими гемороїдальними вузлами 3 ознаками хронічного геморою, які відмовились від гемороїдектомії. Радикальну гемороїдектомію по Мілігану-Моргану виконували пацієнтам при ГТГВ з ознаками хронічного геморою, які погодились на проведення оперативного втручання. При проведенні консервативного лікування тривалість прийому ненаркотичних анальгетиків та терміни перебування у стаціонарі становили $7,8 \pm 1,0$ днів та $15,4 \pm 2,2$ днів відповідно. При проведенні тромбектомії тривалість прийому ненаркотичних анальгетиків зменшилась у 1,8 рази та становила 4,4 $\pm 0,9$ дні, а терміни перебування у стаціонарі зменшились у 1,7 рази до 9,1 1,7 днів, що достовірно менше ніж при проведенні консервативної терапії $(\mathrm{p}<0,05)$. Також достовірно знижується тривалість прийому ненаркотичних анальгетиків у 1,7 рази до

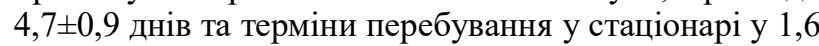
рази до 9,4 41,5 днів при проведенні тромбектомії 3 некректомією у пацієнтів 3 некрозом тканин над тромбованими гемороїдальними вузлами (табл. 3). При проведенні гемороїдектомії по МілігануМоргану тривалість прийому ненаркотичних анальгетиків та терміни перебування у стаціонарі становили $10,4 \pm 1,8$ днів та $19,2 \pm 1,3$ днів. Радикальна гемороїдектомія збільшує тривалість прийому ненаркотичних анальгетиків та терміни перебування у стаціонарі, проте достовірної відмінності з консервативною терапією не виявлено ( $>>0,05)$.

Таблиця 3

Терміни перебування в стаціонарі та тривалість застосування ненаркотичних анальгетиків в залежності від ступеня тяжкості ГТГВ та методу лікування

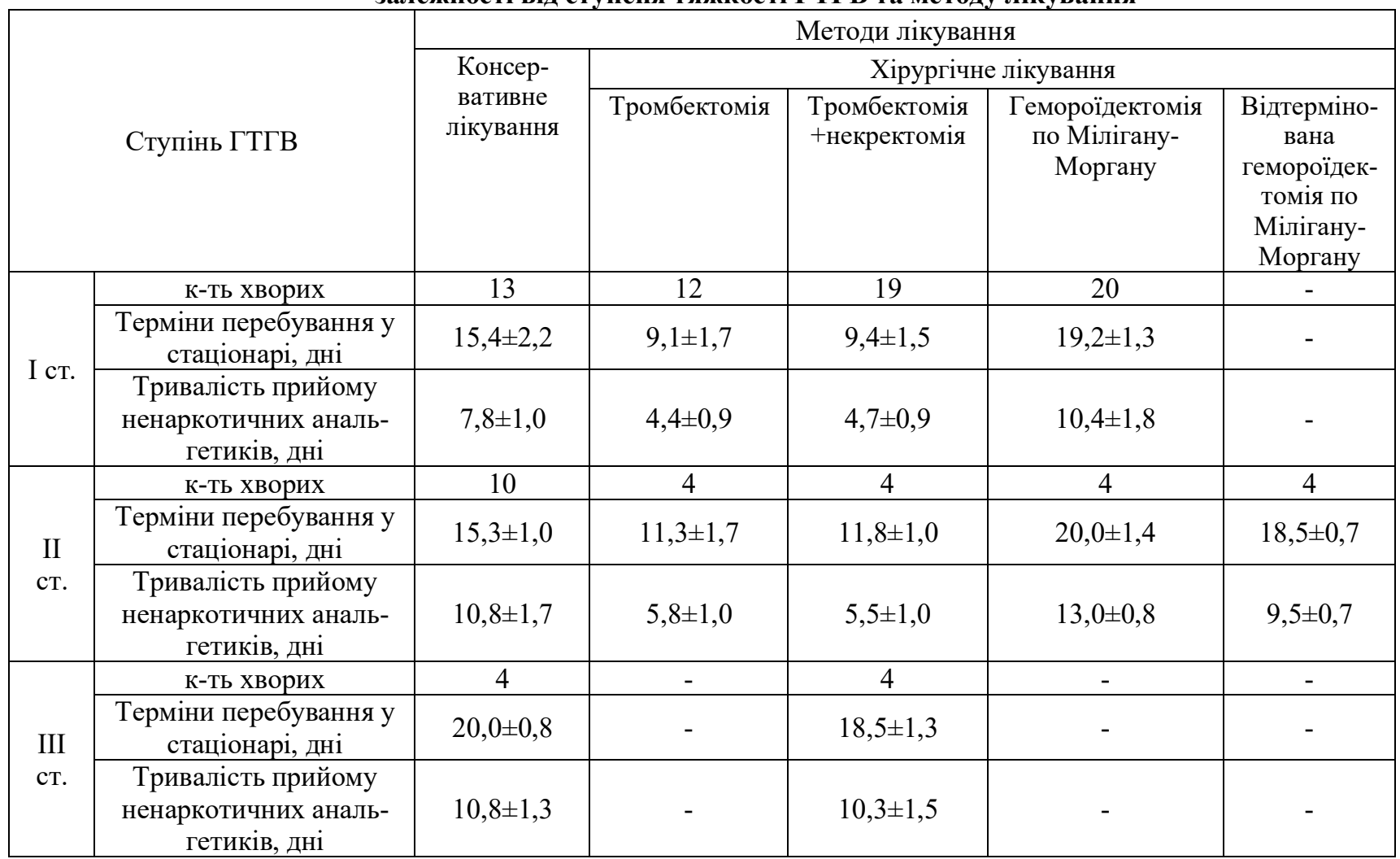


Кількість пацієнтів з ГТГВ ІІ ступеня тяжкості становила 26 (26,5\%) осіб. Консервативне лікування отримували 10 (38,5\%) пацієнтів. Хірургічне лікування проводили у 16 (61,5\%) пацієнтів. 3 них у $4(25,0 \%)$ хворих виконували тромбектомію, у 4 $(25,0 \%)$ хворих - тромбектомію та некректомію, у 8 $(50,0 \%)$ хворих - гемороїдектомію по МілігануМоргану. Тромбектомію виконували пацієнтам, у яких тромбоз виникав повторно та не було ознак хронічного геморою, а також пацієнтам 3 ознаками хронічного геморою, які відмовились від радикальної гемороїдектомії по Мілігану-Моргану. Тромбектомію та некректомію виконували пацієнтам 3 некрозом тканин над гемороїдальними вузлами без ознак хронічного геморою, а також у пацієнтів 3 некрозом тканин над тромбованими гемороїдальними вузлами з ознаками хронічного геморою, які відмовились від гемороїдектомії. Гемороїдектомію виконували пацієнтам при ГТГВ з ознаками хронічного геморою. У 4-ох хворих проведено гемороїдектомію в день поступлення, в інших 4-ох хворих проведено відтерміновану гемороїдектомію по МілігануМоргану через 5,3 $\pm 1,0$ днів після проведення курсу консервативної терапії та зменшення набряку тканин в анальній ділянці. При проведенні консервативного лікування тривалість прийому ненаркотичних анальгетиків та терміни перебування у стаціонарі становили $10,8 \pm 1,7$ днів та $15,3 \pm 1,0$ днів відповідно. При виконанні тромбектомії тривалість прийому ненаркотичних анальгетиків та терміни перебування у стаціонарі становили 5,8 $\pm 1,0$ днів та $11,3 \pm 1,7$ днів відповідно. При проведенні тромбектомії та некректомії тривалість прийому ненаркотичних анальгетиків та терміни перебування у стаціонарі становили $5,5 \pm 1,0$ днів та $11,8 \pm 1,0$ днів відповідно. Проведення тромбектомії та іiї поєднання 3 некректомією дозволили недостовірно зменшити тривалість прийому ненаркотичних анальгетиків та тривалість перебування у стаціонарі у порівнянні 3 консервативною терапією (p>0,05). При проведенні гемороїдектомії по Мілігану-Моргану тривалість прийому ненаркотичних анальгетиків та терміни перебування у стаціонарі значно не відрізнялись від відповідних показників при проведенні консервативного лікування $(\mathrm{p}>0,05)$. Тривалість прийому ненаркотичних анальгетиків при проведенні операції Мілігана-Моргана в день поступлення становила $13,0 \pm 0,8$ днів, при відтермінованій

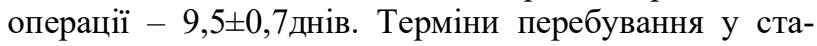
ціонарі при проведенні операції Мілігана-Моргана в день поступлення становила 20,0土1,4 днів, при відтермінованій операції - $18,5 \pm 0,7$ днів. Відтермінування радикальної гемороїдектомії по Мілігану-Моргану до $5,3 \pm 1,0$ днів дозволило достовірно зменшити тривалість застосування ненаркотичних анальгетиків у 1,4 рази ніж при проведенні операції в день поступлення $(\mathrm{p}<0,05)$.

Кількість пацієнтів з ГТГВ ІІІ ступеня становила 8 (8,1\%) осіб. Консервативне лікування отримували 4 (50,0\%) хворих. Хірургічне лікування проводили у 4 (50,0 \%) хворих, яке полягало у проведенні тромбектомії з некректомією. Дану операцію проводили пацієнтам при наявності некрозу тканин над тромбованими гемороїдальними вузлами. У разі від- сутності некрозу тканин пацієнтам проводили консервативне лікування. Всім пацієнтам з ГТГВ III ступеня тяжкості рекомендували проведення гемороїдектомії по Мілігану-Моргану у плановому порядку. Тривалість застосування ненаркотичних анальгетиків та терміни перебування у стаціонарі достовірно не відрізнялись при застосуванні консервативної терапії та проведенні тромбектомії $з$ некректомією ( $>0,05)$. Так, тривалість застосування ненаркотичних анальгетиків при проведенні консервативної терапії становила - 10,8 $\pm 1,3$ днів, при проведенні тромбектомії з некректомією 10,3 $\pm 1,5$ днів. Терміни перебування у стаціонарі при консервативному лікуванні

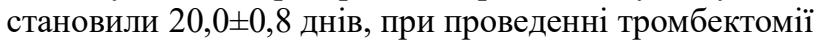
3 некректомією $18,5 \pm 1,3$ днів.

\section{Висновки:}

1. При ГТГВ І ступеня тяжкості тривалість застосування ненаркотичних анальгетиків та строки перебування у стаціонарі значно не відрізнялись при проведенні консервативної терапії та виконанні гемороїдектомії по Мілігану-Моргану. Тому пацієнтам 3 ознаками хронічного геморою доцільно проводити радикальне видалення гемороїдальних вузлів.

2. Тромбектомія та поєднана тромбектомія 3 некректомією у пацієнтів з ГТГВ І ступеня тяжкості без ознак хронічного геморою та 3 наявним хронічним гемороєм, які відмовились від радикальної операції, дозволяє скоротити терміни перебування у стаціонарі у $1,7 \pm 0,07$ рази та зменшити у $1,8 \pm 0,07$ рази тривалість прийому знеболювальних препаратів.

3. Відтермінування радикальної гемороїдектомії по Мілігану-Моргану на 5,3土1,0 днів та проведення курсу консервативної терапії до зменшення набряку тканин дозволяє покращити лікування пацієнтів 3 ГТГВ II ступеня тяжкості та зменшити у 1,4 рази тривалість застосування ненаркотичних анальгетиків.

\section{References:}

1. Ahmadova EV et al. Our Results in the Surgical Treatment of Acute Hemorrhoidal Thrombosis. J Gastrointest Disord Liver Func. 2017; 3(1):98- 99.

2. Blagodarnyiy LA. Oslozhnennyiy gemorroy: diagnostika i lechenie. Ambulatornaya hirurgiya statsionarozameschayuschie tehnologii . 2015; 3-4: (5960). P.29 - 34.

3. Chobei SM. Vykorystannia bioflavonoidiv u kompleksnomu likuvanni hemoroiu. Naukovyi visnyk Uzhhorodskoho universytetu. Seriia : Medytsyna. 2015.

4. Hardy A, Cohen CR. The acute management of hemorrhoids. Ann. R Coll Surg Engl 2014; 96:508-511.

5. Langfassung der S3-Leitlinie 081/007: Hämorrhoidalleiden, 2019.

6. Lee JH, Kim HE, Kang JH, Shin JY, Song YM. Factors associated with hemorrhoids in korean adults: korean national health and nutrition examination survey. Korean J Fam Med. 2014; 35:227-236.

7. Statistika : uchebnik i praktikum dlya SPO. pod red. VG Minashkina. M. : Izdatelstvo Yurayt, 2018. P.448. Seriya : Professionalnoe obrazovanie. ISBN 978-5-53403465-3

8. Perrotti P, Antropoli C, Molino D et al. Conservative treatment of acute thrombosed external hemorrhoids with 
topical nifedipine. Dis Colon Rectum. 2001; 44(3):405409.

9. Riss S, Weiser FA, Schwameis K, Riss T, Mittlböck M, Steiner G, Stift A. The prevalence of hemorrhoids in adults. Int J Colorectal Dis. 2012; 27:215-220.

10. Fontem Rodrigue F, Bhimji Steve $\mathrm{S}$. Internal Hemorrhoid. Treasure Island (FL): StatPearls Publishing; 2019, Jan; PMID: 30725867.

\section{УДК 616-005.6+616.147.17-007.64+616-071+616-089 \\ ОСТРЫЙ ТРОМБОЗ ГЕМОРРОИДАЛЬНЫХ УЗЛОВ: КЛИНИЧЕСКИЙ ПРОФИЛЬ ПАЦИЕНТА И ЛЕЧЕБНАЯ ТАКТИКА}

\section{Ю.Б. Киндракевич, В.И. Пилипчук, А.Л. Шаповал}

Ивано-Франковский национальный медицинский университет, кафедра хирургии № 2 u кардиохирургии, г. Ивано-Франковск, Украина, ORCID ID: 0000-0003-2891-8035,

ORCID ID: 0000-0002-3754-4592,

ORCID ID: 0000-0002-7950-1451, e-mail:kjb82@ukr.net

Резюме. Цель исследования - определить клинический профиль пациента и сравнить результаты консервативного и хирургического лечения острого тромбоза геморроидальных узлов.

Методы. В течение 2014-2018 гг. в проктологическом отделении Ивано-Франковской областной клинической больницы лечились 98 пациентов с острым тромбозом геморроидальных узлов. Среди них $60(61,2 \%)$ мужчин, 38 (38,8 \%) женщин. Для определения клинического профиля пациентов с острым тромбозом геморроидальных узлов изучали жалобы пациентов при поступлении, возможные причины возникновения заболевания, продолжительность заболевания до обращения за помощью, данные объективного обследования. Связь между жалобами и данными объективного обследования определяли с помощью коэффициентов ассоциации и контингенции. Оценивали влияние консервативного и хирургического лечения острого тромбоза геморроидальных узлов на длительность применения ненаркотических анальгетиков и сроки пребывания в стационаре.

Результаты исследования. У пациентов с острым тромбозом геморроидальных узлов I степени тяжести продолжительность приема ненаркотических анальгетиков и сроки пребывания в стационаре сокращаются в 1,8 и 1,7 раза соответственно, при проведении тромбэктомии, и в 1,7 и 1,6 раза соответственно, при проведении тромбэктомии в сочетании с некрэктомией. Продолжительность приема ненаркотических анальгетиков сокращается в 1,4 раза при отсроченой геморроидэктомии по Милиган-Моргану до 5,3 $\pm 1,0$ дней при II степени тяжести.

Выводы. При остром тромбозе геморроидальных узлов I степени тяжести нужно придерживаться активной хирургической тактики, при II-III степени тяжести проводить хирургическое лечение после уменьшения отека, признаков воспаления и курса консервативной терапии.

Ключевые слова: геморрой, тромбоз, острый, клиника, лечение.

\section{UDC 616-005.6+616.147.17-007.64+616-071+616-089 ACUTE THROMBOSIS OF HEMORRHOIDS: PATIENT CLINICAL PROFILE AND TREATMENT}

\author{
Y.B. Kindrakevych, V.I. Pylypchuk, A.L. Shapoval
}

Ivano-Frankivsk National Medical University, department of Surgery №2 and cardiacs Surgery, Ivano-Frankivsk, Ukraine,

ORCID ID: 0000-0003-2891-8035,

ORCID ID: 0000-0002-3754-4592,

ORCID ID: 0000-0002-7950-1451,

e-mail:kjb82@ukr.net

\begin{abstract}
The purpose was to study the clinical profile of patients who seek help with acute thrombosis of hemorrhoids and to establish a link between complaints and objective examination by means of determining the association and contingency ratios; and to analyze the influence of methods of treatment of acute thrombosis of hemorrhoids on duration of non-narcotic analgesics use and stay in a hospital.
\end{abstract}

Methods. During 2014-2018, 504 patients were treated for the hemorrhoids in the Ivano-Frankivsk Regional Clinical Hospital. Among them, 98 patients with acute thrombosis of hemorrhoids, which is $19.4 \%$ of all patients with hemorrhoids. There were $60(61.2 \%)$ men and $38(38.8 \%)$ women. The average age of patients was $47.9 \pm 15.3$ years. To determine the clinical profile of patients with acute thrombosis of hemorrhoids, the complaints were studied at admission, the possible causes of the disease, the duration of the disease before treatment, the data of objective examination. The relationship between complaints and the objective survey data was determined using association and contingency ratios. The influence of conservative and surgical treatment of acute thrombosis of hemorrhoids on the duration of nonnarcotic analgesics use and the length of stay in hospital were evaluated.

Results. Among the appeals for medical aid for hemorrhoids, the fifth part consists of patients with acute thrombosis of hemorrhoids. Basically, these are patients of working age. For acute thrombosis of hemorrhoids, such symptoms as pain, bleeding, the presence of "formation" in the anal area are considered to be characteristic. Appeal for three days from the onset of the disease indicates a pronounced pain syndrome. In $70.0 \%$ of patients, with complaints of bleeding, with objective examination revealed necrosis of tissues over thrombosed node. $61.1 \%$ of patients with constipation had swelling of the tissues of the anal area. In patients with acute thrombosis of hemorrhoids of severity degree I, the duration of non-narcotic analgesicsthe use and the terms of stay in the hospital are reduced in 1.8 and 1.7 times, respective- 
ly, during thrombectomy, 1.7 and 1.6 times, respectively, during thrombectomy in combined with necrectomy. The duration of non-narcotic analgesics use is reduced in 1.4 times when delayed hemorrhoidectomy by MiliganMorgan to $5.3 \pm 1.0$ days with severity degree II.

Conclusions. In acute thrombosis of hemorrhoids severity degree I, the duration of non-narcotic analgesics use and the duration of stay in the hospital did not differ significantly in the course of conservative therapy and the implementation of hemorrhoidectomy in Miligan-Morgan. Thrombectomy and combined thrombectomy with necretomy in patients with acute thrombosis of hemorrhoids severity degree I without signs of chronic hemorrhoids, and those with chronic hemorrhoids who have renounced radical surgery, can reduce the hospital stay in $1.7 \pm 0.07$ times and decrease in $1,8 \pm 0,07$ times the duration of administration of anesthetics. Therefore, in acute thrombosis of hemorrhoids severity degree I, one must adhere to active surgical tactics. In acute thrombosis of hemorrhoidal nodes of severity degree IIIII, surgical treatment is advisable after reduction of edema, signs of inflammation and course of conservative therapy.

Keywords: hemorrhoids, thrombosis, acute, clinic

Стаття надійшла в редакцію 17.07. 2019 р. 